\title{
ガスデポジション法によるリチウム薄膜及び合金薄膜の 作製と電極特性
}

\author{
山川 幸雄 ${ }^{\mathrm{a}}$, 和田 仁 ${ }^{\mathrm{b}}$, 境哲男 ${ }^{\mathrm{c}}$ \\ a本城金属株式会社（一 578-0984 東大阪市菱江 2-3-8） \\ b 福田金属䈃粉工業株式会社（† 607-8305 京都市山科区西野山中臣町 20） \\ c 産業技術総合研究所, 関西センター（† 563-8577 池田市緑丘 1-8-31）
}

\section{Preparation of Lithium Thin Film and Alloy Thin Film by Gas Deposition Method and Their Electrode Properties}

\author{
Yukio YamaKawa, ${ }^{\mathrm{a}}$ Masashi WADA, ${ }^{\mathrm{b}}$ and Tetsuo SAKAI ${ }^{\mathrm{c}}$
}

\begin{abstract}
${ }^{a}$ Honjo Metal Co., Ltd. (2-3-8, Hishie, Higashi Osaka 578-0984, Japan)
${ }^{b}$ Fukuda Metal Foil \& Powder Co., Ltd. (20, Nakatomicho, Nishinoyama, Ymashina-ku, Kyoto, 607-8305, Japan)

'National Institute of advanced Industrial Science and Technology (AIST), Kansai (1-8-31 Midorigaoka, Ikeda, Osaka 563-8577, Japan)
\end{abstract}

Received August 24, 2007 ; Accepted December 18, 2007

\begin{abstract}
We have succeeded to make a Li metal thin film in the range of 1-20 $\mu \mathrm{m}$ on copper foil or plastic thin film by gasdeposition method. The Li thin films showed almost the same discharge capacity as a conventional Li metal foil made by roll-pressing method. Alloy thin film electrode of a Sn-35mass \% Cu also has been prepared on copper film by the gas-deposition method. The gas-deposited electrode showed much higher capacity retention ratio (87\% after 50 cycles) than the conventional pasted electrode (20\% after 50 cycles). The initial irreversible capacity loss of roughly $30 \%$ in the alloy electrode have been suppressed successfully by pre-doping of lithium in the alloy electrode using the lithium thin film prepared on the plastic sheet.
\end{abstract}

Key Words : Li Thin Film, Gas-deposition, Alloy Thin Film, Alloy Negative Electrode, Irreversible Capacity

\section{1 緒 言}

リチウムイオン電池は，携帯型電子機器の電源として広く 利用されているが，情報通信量の増大とともに，更なる高容 量化が求められ, 新規電極新材料の開発が活発に行われてい る，負極においては，炭素系負極材料の高容量化が限界にき ている中で， $\mathrm{Li}$ 金属 ${ }^{1)}$ や合金系 ${ }^{2-4)}$ が次世代高容量負極材料 として，実用化が検討されている。

$\mathrm{Li}$ 金属負極では，従来の押出し成形や圧延法では $30 \mu \mathrm{m}$ 以 下の薄膜しかできない課題がある。そこで，真空蒸着法や熱 還元法などによる Li 薄膜作製が検討されてきたが，真空チ ヤンバー壁にLiが付着して取り扱いが面倒なことや, 高温 でLiの酸化劣化が起きやすいなどの問題があり, 低温での $\mathrm{Li}$ 薄膜形成法の開発が期待されていた.

合金系負極では，Li吸蔵により大きな体積変化が生じ，微 粉化によりサイクル寿命が短くなることや初期不可逆容量が 大きいなどの課題がある。太陽工鉱の吉永らは, V-Sn 系合 金を検討して，従来の粉末ペースト塗布法で作製した電極で は50サイクル以下の寿命しか得られないが，スパッタリン グ法で作製した合金薄膜電極では，300サイクル後でも $80 \%$ の容量維持ができると報告している ${ }^{5)}$. また， シリコン系材
料でも, 従来の塗布電極では数サイクルで急激な容量低下が 見られるが，スパッタリング法で銅䇤基材上に $\mathrm{Si}$ 薄膜を形成 した電極では，その膜厚にも依存するが，100サイクル以上 のサイクル寿命が得られている ${ }^{6)}$. 鳥取大学の坂口らは, 従 来の塗布電極では寿命が数サイクルでしかなかった $\mathrm{Mg}_{2} \mathrm{Ge}$ 粉末を用いて, ガス流で基材上に吹き付けて製膜するガスデ ポジション法を適用して電極作製したところ，200サイクル 後でも $80 \%$ の容量維持ができたと報告している7,8)。このよ うに合金と基材との密着性が，電極のサイクル寿命を律する 大きな因子であることが分かる。

本研究では, 不活性ガス流で $\mathrm{Li}$ 蒸発微粒子を運び, 基材 上に噴射堆積させるガスデポジション（GD）法を利用して， 銅箔やプラスチックシート上に良質の $\mathrm{Li}$ 金属薄膜を形成さ せる手法を開発した。 また，同様な方法で，Sn-35mass\% $\mathrm{Cu}$ 合金粉末を，銅箔上に堆積した合金薄膜電極を作製した ところ，従来のペースト電極に比べて大幅な長寿命化ができ た. 更に，この合金電極上にプラスチックシート上に形成し た $\mathrm{Li}$ 薄膜を転写して，これを熱拡散させることで初期不可 逆容量をほぼゼロにできることも見出したので報告する. 


\section{$2.1 \mathrm{Li}$ 薄膜の作製と評価}

\section{2 実 験}

Fig. 1 に GD 法による Li 薄膜作製方法を示す．生成室での 雲囲気を $\mathrm{He}$ として， $450-700{ }^{\circ} \mathrm{C} て ゙$ 金属 Li塊を加熱することで $\mathrm{Li}$ ナノ粒子を生成させ，これを $\mathrm{He}$ ガス流で搬入管を通して 生成室圧力以下に減圧した成膜室に搬送し，噴射圧力を 25 〜90 kPaの範囲で調整して, 銅箔上またはポリプロピレン フィルム $(\mathrm{PP})$ 上に噴射堆積させることで $\mathrm{Li}$ 薄膜（1 $20 \mu \mathrm{m} ）$ を形成した.

$\mathrm{GD}$ 法で銅箔上に作製した $1 \sim 20 \mu \mathrm{m}$ 厚みの $\mathrm{Li}$ 薄膜電極 (面積 $1 \mathrm{~cm}^{2}$ ) を用いて，対極に $\mathrm{Li}$ 箔，電解液として $1 \mathrm{~mol} / 1$ $\mathrm{LiClO}_{4}$ プロピレンカーボネートを用いたコインセルを作製し， 電流密度 $2 \mathrm{~mA} \mathrm{~cm} \mathrm{~cm}^{-2}$, 測定電圧幅 $0-1 \mathrm{~V}$, 温度 $303 \mathrm{~K}$ の条

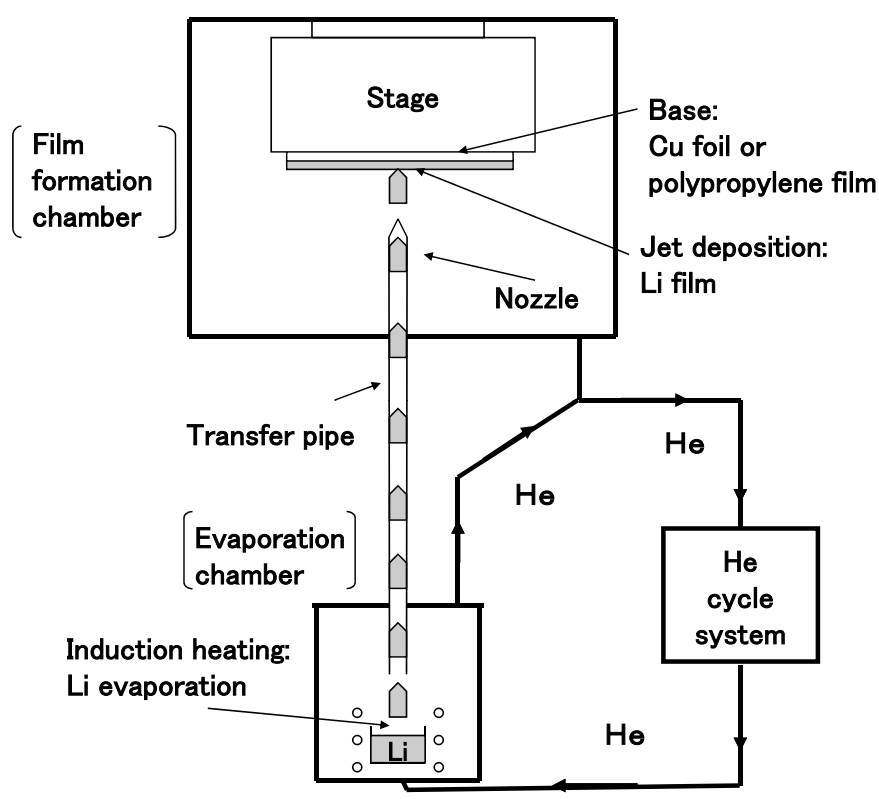

Fig. 1 The Outline of production process for the lithium thin films by the gas-deposition method.

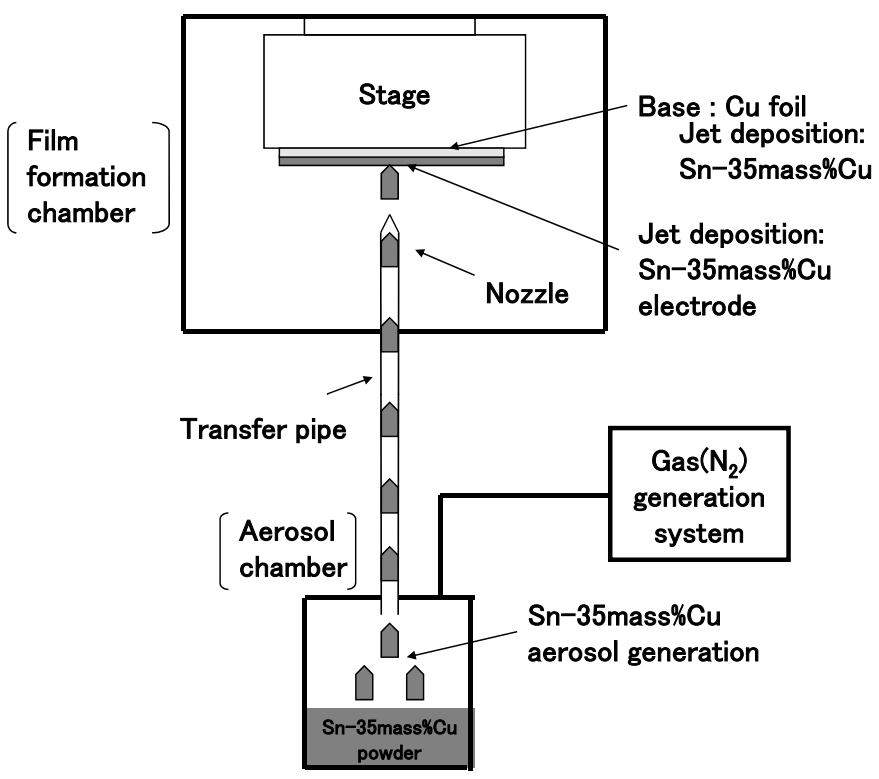

Fig. 2 The Outline of production process for the alloy electrodes by the gas-deposition method.
件下で定電流放電試験を行った。

\section{2 合金電極の作製と評価}

合金原料は, Sn-35mass \% Cu 組成（真密度は7.5 $\mathrm{g} \mathrm{cm}^{-3}$ ) で，一次粒子径が $1 \mu \mathrm{m}$ 以下で二次凝集平均粒径を 5 〜 $10 \mu \mathrm{m}$ に調整した粉末を用いた。 Fig. 2 にGD法による合金 電極（GD電極）の作製方法を示す．室温で，予め合金粉末 をエアロゾル室に装填しておき，これをキャリアガス $\left(\mathrm{N}_{2}\right)$ 流で搬入管を通して減圧された成膜室に搬送し，噴射圧力を $10 \sim 80 \mathrm{kPa}$ の範囲で調整して, 銅箔上に合金堆積膜を形成 した。なお，導電助剤やバインダーは添加していない。

$\mathrm{Sn}-35 \mathrm{mass} \% \mathrm{Cu}$ 組成の複合粉末及び $\mathrm{GD}$ 電極の結晶構造を, $\mathrm{X}$ 線回折法（XRD）で調べた。また，合金堆積層の見かけ密 度を測定し，合金真密度との比から堆積層の多孔度を求めた。 充放電サイクル試験前と 300 サイクル後の電極表面形態を SEM で観察した。

更に，GD電極上に，PPフィルム上に形成した GD 電極不 可逆容量分に相当する $\mathrm{Li}$ 薄膜 (厚み $3.7 \mu \mathrm{m}, 0.2 \mathrm{mg} \mathrm{cm}{ }^{-2}$ ) を貼り合わせてロールプレスすることで，圧着，転写した． その後, $373 \mathrm{~K}$ で 1 時間, 真空下で熱処理することで, $\mathrm{Li}$ ド ープを行った.

従来の塗布電極は，合金粉末 85 重量部にN-メチルピロリ ドン（NMP）に溶解したポリビニリデンフルオライド (PVdF) 10 重量部，カーボンブラック 5 重量部を混合して スラリーとして，これをドクターブレード法で電解銅箔に均 一に塗布 $\left(40\right.$ ～ $\left.50 \mathrm{~g} \mathrm{~m}^{-2}\right)$ することで作製された。これを $353 \mathrm{~K}$ で約 10 分間乾燥してNMP溶液を揮発・除去した後, ロールプレス成形して，電極活物質層の平均厚さ約 $10 \mu \mathrm{m}$ の シートを作製した。これを $1 \mathrm{~cm}^{2}$ の円形に打ち抜き， $393 \mathrm{~K}$ で 3 時間，真空乾燥させて，塗布電極とした。

これらの GD 電極などを用いて，対極に $\mathrm{Li}$ 箔，電解液とし て $1 \mathrm{~mol} / 1 \mathrm{LiPF}_{6}$ エチレンカーボネート/ジエチレンカーボネ ート = 1：1の構成でコインセルを作製し， $0.2 \mathrm{~mA} \mathrm{~cm}^{-2}$, 測定電圧 $0-1 \mathrm{~V}$, 温度 $298 \mathrm{~K}$, もしくは $0.2 \mathrm{~mA} \mathrm{~cm}^{-2}$, 測定 電位幅 0-1.5 V, 温度 $303 \mathrm{~K}$ の条件下で定電流充放電試験を 実施した。

\section{3. $1 \mathrm{Li}$ 薄膜の作製と評価}

\section{3 結果および考察}

$\mathrm{Li}$ 薄膜作製時, 真空チャンバー内の壁への $\mathrm{Li}$ の飛散は見 られず，蒸発量相当分の膜を作製できた，Liは，大気中の水 分と反応して発火等を起こす危険性を有しているが， $\mathrm{Li}$ 金属

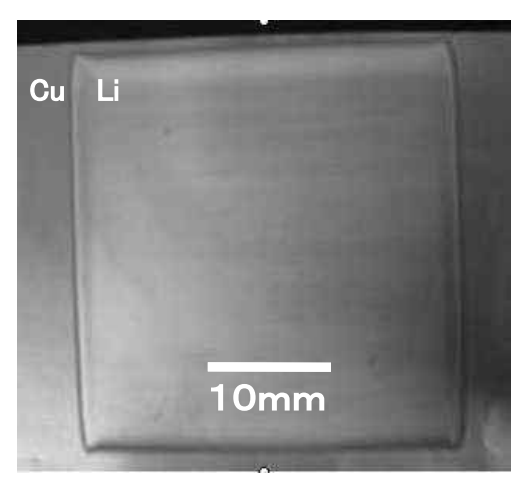

Fig. 3 Appearance of the lithium thin film deposited on the $\mathrm{Cu}$ foil. 
のチャンバー内での飛散を抑制できたことで膜作製後の装置 のメンテナンスも安全に行えた。また，GD法では成膜時の 温度上昇が少ないためPP（溶融温度 $433 \mathrm{~K}$ ）のようなプラス チック基材上にも $\mathrm{Li}$ 薄膜を形成できることがわかった。

Fig. 3 に銅簿（10 $\mu \mathrm{m}$ 厚み）上に作製した Li 薄膜（膜厚 1 $\sim 20 \mu \mathrm{m}$ : 面積 $\left.9 \mathrm{~cm}^{2}\right)$ の外観を示す。この $\mathrm{Li}$ 薄膜では, 従 来の圧延ロール法で作製した $\mathrm{Li}$ 箔と同様，銀白色の表面色 であることから，酸化や窒化の影響はほとんど受けていない ものと考えられた. Fig. 4 に $10 \mu \mathrm{m}$ 厚の Li薄膜電極の初期放 電曲線を示す．表面の酸化や窒化に由来するような分極はな く平坦な放電曲線が得られた。 Fig. 5 に Li 薄膜の膜厚と放電 容量の関係について, 実測值と理論值を比較して示す. Li 薄 膜は，厚み $1 \sim 20 \mu \mathrm{m}$ の広範囲において，Li理論值である $3861 \mathrm{Ah} / \mathrm{kg}$ に対して $90 \sim 100 \%$ の放電容量が得られており, 表面劣化のない良質な Li 薄膜が得られていることが確認で きた。

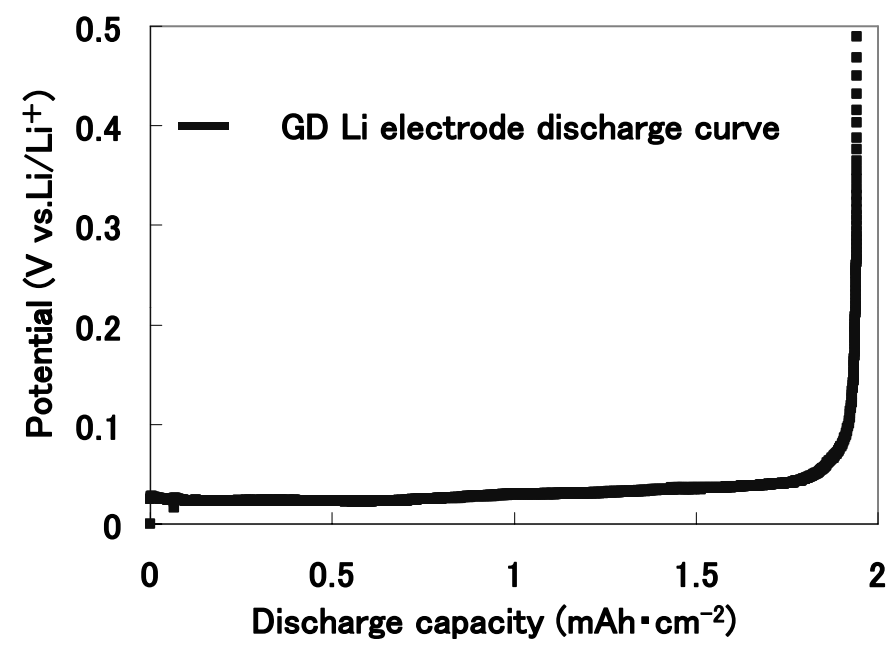

Fig. 4 The first discharge curve of the lithium thin film deposited on the $\mathrm{Cu}$ foil. (Current density: $2 \mathrm{~mA} \mathrm{~cm}^{-2}$, Temperature : $303 \mathrm{~K}$, Cut off voltage : 0-1 V vs. $\mathrm{Li} / \mathrm{Li}^{+}$)

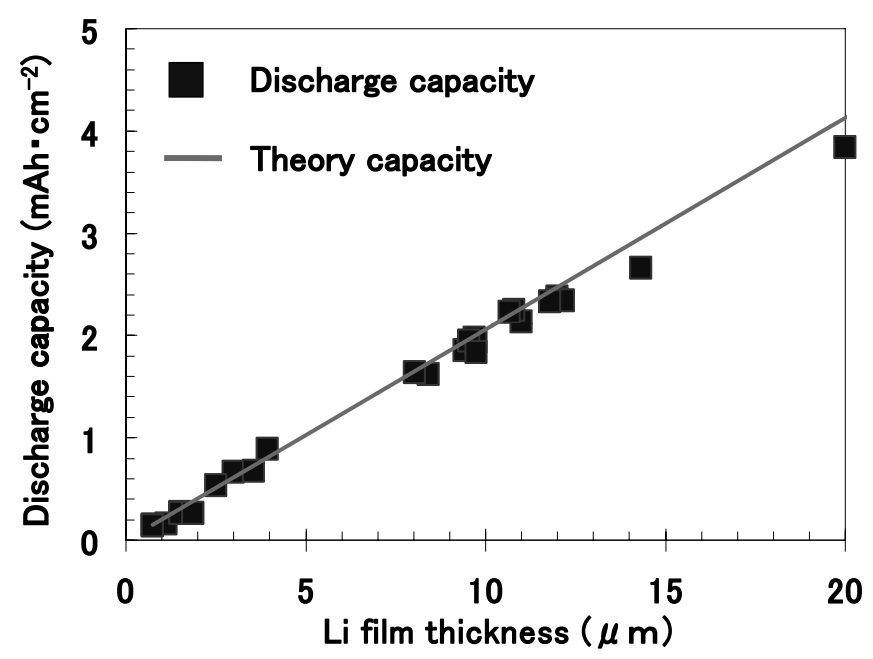

Fig. 5 The relationship between the Li film thickness and discharge capacity for the lithium thin film deposited on the $\mathrm{Cu}$ foil.

\section{2 Sn-35mass \% Cu電極の作製と評価}

$\mathrm{GD}$ 法を用いた $\mathrm{Sn}-35 \mathrm{mass} \% \mathrm{Cu}$ の堆積速度は，1 $20 \mu \mathrm{m} / \mathrm{min}\left(9 \mathrm{~cm}^{2}\right.$ の面積当たり）であり，真空蒸着法など の気相法の成膜速度 $(0.03 \sim 0.5 \mu \mathrm{m} / \mathrm{min})$ に比べ 40 倍以上 大きいことがわかった．ただ，供給した原料粉末のうちで銅 䇴上に堆積できた割合（粉末利用効率）はまだ $1 \%$ 以下と低 いため, 実用化のためには, 未堆積分の原料粉末の回収・再 利用などを含めて検討する必要がある.

Fig. 6 に銅䇴上に堆積した $\mathrm{Sn}-35 \mathrm{mass} \% \mathrm{Cu}$ 薄膜の外観を示 す．銅箔には，成膜時の衝撃によるしわや龟裂などの損傷は 見られなかった.Fig. 7 （a）に複合粉末のSEM像を示すが， $1 \mu \mathrm{m}$ 以下の一次粒子からなる粉末凝集体（平均粒径 5 〜 $10 \mu \mathrm{m} ）$ であることが分かる.Fig. 7（b）に製膜したSn$35 \mathrm{mass} \% \mathrm{Cu}$ 薄膜の SEM 像を示すが，表面には粒子形状を 反映した凹凸が見られるものの，粒子同士が互いに融合した 緻密な薄膜を形成していることが分かる.Fig. 8 に原料粉末， 及びその薄膜電極の XRD パターンを比較して示す。原料粉 末では，主相である $\mathrm{Cu}_{6} \mathrm{Sn}_{5}$ 相に加えて， $\mathrm{Sn}$ 相と $\mathrm{Cu}$ 相が観察 される。薄膜電極では，主相である $\mathrm{Cu}_{6} \mathrm{Sn}_{5}$ 相はそのままで, 新たに $\mathrm{SnO}_{2}$ 相が現れ， $\mathrm{Sn}$ 相由来のピークは消失した. $\mathrm{SnO}_{2}$ 相が生成した理由は不明であるが，薄膜形成時の雲囲気中に は酸素がわずかなに残存していたためかもしれない。

Fig. 9 に薄膜電極と塗布電極のサイクル特性を比較して示 す.塗布電極では，50サイクル後には，放電容量が初期の $20 \%$ ま゙低減した。一方，薄膜電極の放電容量は，50サイ クル後で初期の $87 \%$ ，300 サイクル後でも $30 \%$ が維持され

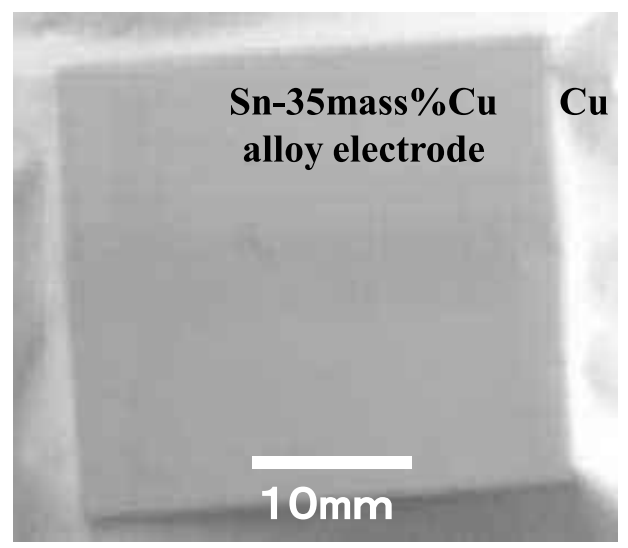

Fig. 6 Appearance of the alloy thin film (Sn-35mass \% Cu) deposited on the $\mathrm{Cu}$ foil.
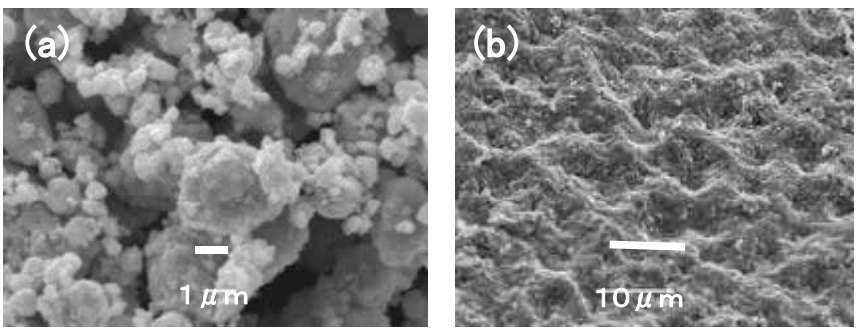

Fig. 7 The SEM image of the composite powder (Sn$35 \mathrm{mass} \% \mathrm{Cu}$ ) (a) and the gas-deposited alloy electrode on the $\mathrm{Cu}$ foil (b). 


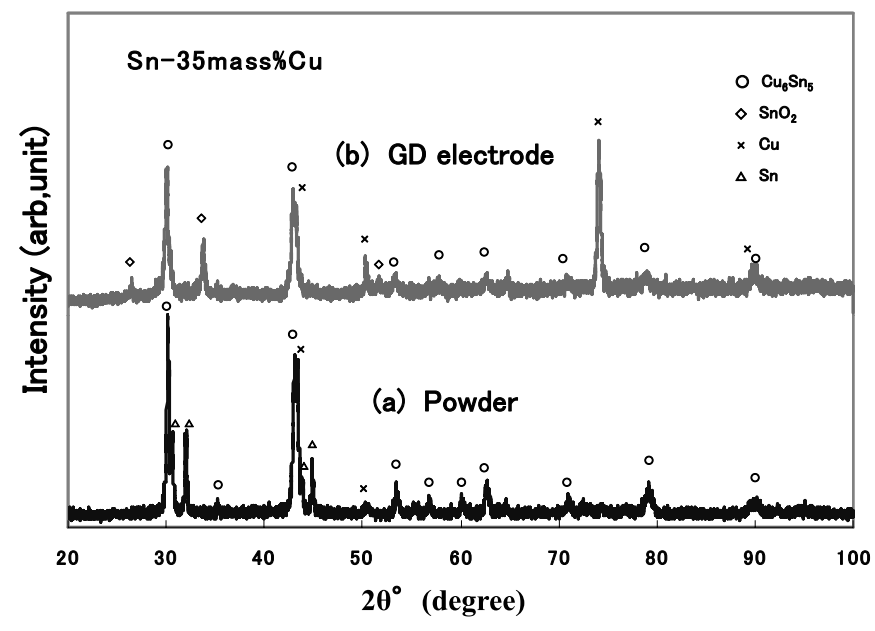

Fig. 8 The XRD patterns for the composite powder (a) and the gas-deposited alloy electrode on the $\mathrm{Cu}$ foil (b).

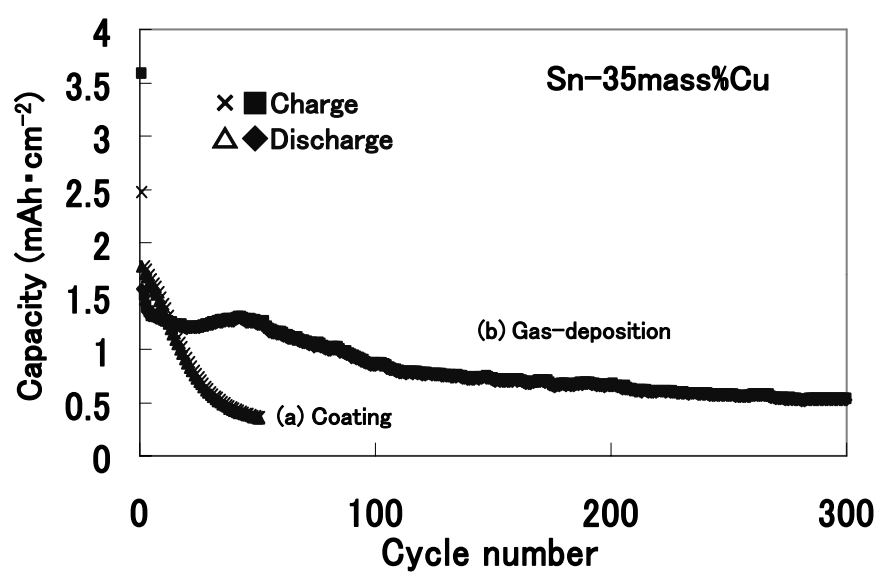

Fig. 9 The comparison of cycling performances for the Sn$35 \mathrm{mass} \% \mathrm{Cu}$ alloy electrodes prepared by the conventional coating method (a) and the gas-deposition method (b). (Current density : $0.2 \mathrm{~mA} \mathrm{~cm}{ }^{-2}$, Temperature: $298 \mathrm{~K}$, Cut off voltage : $0-1 \mathrm{~V}$ vs. $\mathrm{Li} / \mathrm{Li}^{+}$)

ており，サイクル寿命の大幅な改善が見られた。Fig.10に 300 サイクル後の電極表面 SEM像を示すが，従来の薄膜電極 で報告されているような電極表面上でのクラック形成や脱落, 活物質の微粉化などは見られない。このことから，GD 法で は，合金粒子間及び合金粒子と銅䇴間において良好な密着性 が得られることが分かった。これらの結合形態については, 現在検討中であるが，このような小さな噴射圧力（10～ $80 \mathrm{kPa}$ ）においても，合金粒子間の強固な結合ができること はきわめて興味深い.また，合金の密度と電極体積から見積 もった GD 電極の多孔度は $40 \sim 50 \%$ 程度となり，合金粒子 間の空隙を反映して多孔構造の薄膜電極が形成されているこ とがわかった。このように合金粉末が三次元的に強固に結合 した多孔性電極が，銅箔基材上に密着して形成されることで， Li吸蔵時の大きな体積変化にも耐えられる合金電極が実現で き，サイクル寿命が顕著に向上したものと考えられたこのの ようにGD法は，バインダーや導電助剤を用いない多孔性電 極の作製法として，充放電に伴う体積変化の大きな合金系電 極に有用な製造方法といえる。

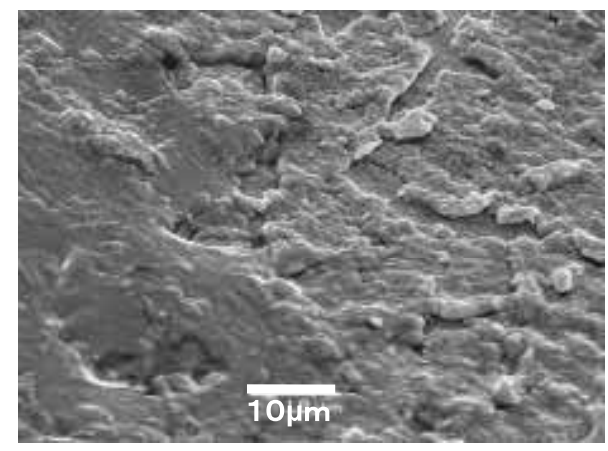

Fig. 10 SEM image of the gas-deposited alloy electrode after 300 cycles.

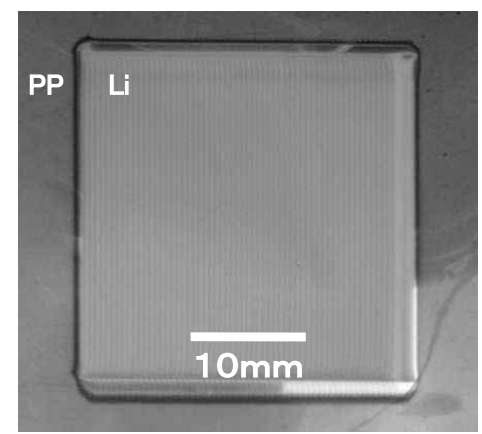

Fig. 11 Appearance of the lithium thin film deposited on polypropylene film.

\section{3 GD電極への $\mathrm{Li}$ ドープと評価}

$\mathrm{Sn}-35 \mathrm{mass} \% \mathrm{Cu}$ 薄膜電極の大きな初期不可逆容量を改善 するために，Li ドープを検討した．Fig. $11 に P P ~(50 \mu \mathrm{m}$ 厚 み）上に作製した $\mathrm{Li}$ 薄膜（膜厚 $1 \sim 20 \mu \mathrm{m}$ ：面積 $9 \mathrm{~cm}^{2}$ ）の 外観を示す。 PPシート上に作製した Li 薄膜では，銅箔上に 形成した場合と比べて基材との密着力は低いため，ロールプ レス機等を用いて，電極表面への転写が容易にできることが 分かった. 電極への Li転写後, $373 \mathrm{~K}$ で真空下， 1 時間の熱 処理によって Li ドープを行った. Fig. 12 Liドープ電極の 初期充放電曲線を, 未ドープ品と比較して示す. 未ドープ品 では, 約 30\%の初期不可逆容量が存在したが, Li ドープ電 極は初期不可逆容量がほとんどない. Fig. 13 にLiドープ電 極のサイクル特性を未ドープ品と比較して示す. Li ドープに よって不可逆容量は消滅したが, サイクル特性には大きな影 響がないことが分かる。このようにPPシート上に作製した $\mathrm{Li}$ 薄膜を，合金電極上にその不可逆容量分相当を転写して， 熱拡散させることで, 初期不可逆容量を完全にキャンセルで きることを実証できた。この技術は，合金電極の実用化にお いて，大変重要になると思われる.

\section{4 結 論}

GD 法を用いることで，従来の圧延法では困難であった 1 〜 $20 \mu \mathrm{m}$ 厚みの Li 薄膜の作製に成功した。また, Sn$35 \mathrm{mass} \% \mathrm{Cu}$ 合金電極を GD 法で作製した結果，銅箔との密 着性に優れた多孔性電極が得られた，放電容量は 50 サイク ル後で初期容量の $87 \%$ が維持され, 従来の塗布電極（50サ イクル後の容量維持率 $20 \%$ ）に比べて顕著にサイクル寿命 


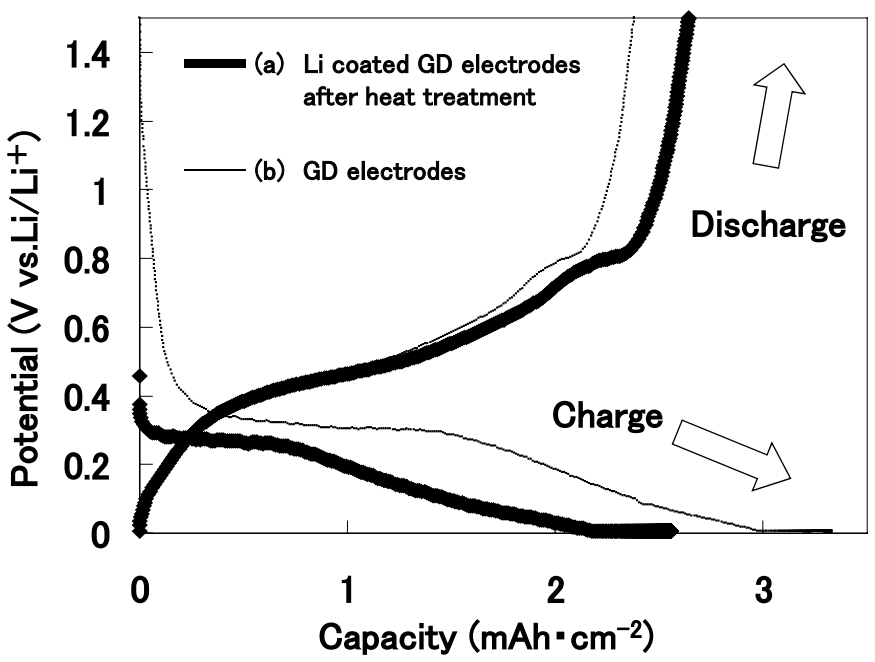

Fig. 12 The charge-discharge curves for the Sn-35mass\% $\mathrm{Cu}$ gas-deposited electrodes with the Li-doping (a) and without Li-doping (b). (Current density: $0.2 \mathrm{~mA} \mathrm{~cm}^{-2}$, Temperature : $303 \mathrm{~K}$, Cut off voltage : 0-1.5 V vs. $\mathrm{Li} / \mathrm{Li}^{+}$)

の改善ができた，次に，作製した合金電極の大きな不可逆容 量（約 $30 \%$ ）を低減するために，PP シート上に製膜した Li 薄膜を合金電極上に転写して，これを合金中に熱拡散させる Li ドープ技術を確立した。今後，合金電極の更なる高容量化 と長寿命化のために，合金組成及び電極製造条件について検 討を進める予定である。

\section{文 献}

1) T. Fujieda, Materia Japan, 38, 488 (1999) [in Japanese] .

2) T. Sakai, Electrochemistry, 71, 723 (2003) [in Japanese].

3) M. Wada, J. Yin, E. Tanabe, Y. Kitano, S. Tanase, O. Kajita, and T. Sakai, Electrochemistry, 71, 1064 (2003).

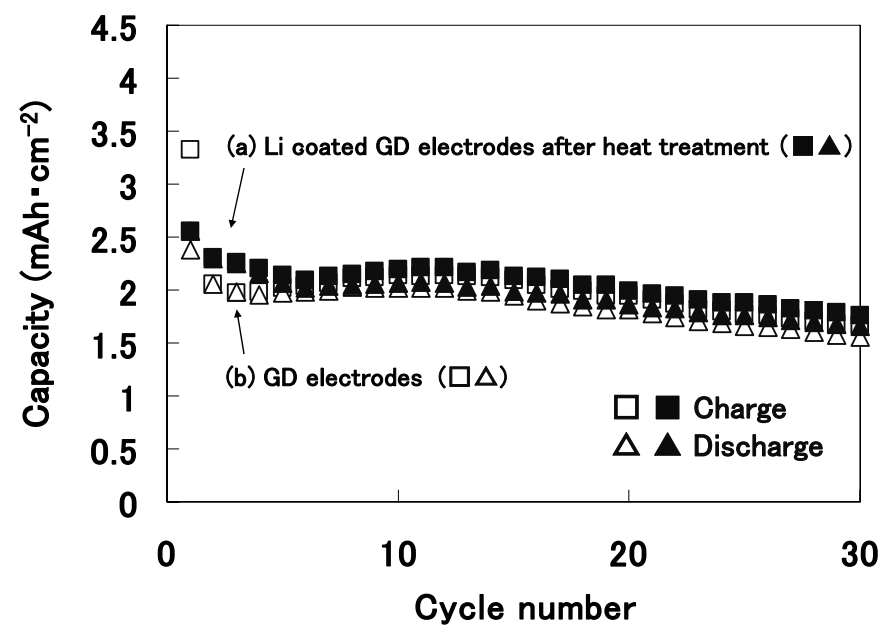

Fig. 13 The cycling performances for the Sn-35mass \% Cu gas-deposited electrodes with Li-doping (a) and without Lidoping (b). (Current density: $0.2 \mathrm{~mA} \mathrm{~cm}^{-2}$, Temperature: 303 K, Cut off voltage: $0-1.5 \mathrm{~V}$ vs. $\mathrm{Li} / \mathrm{Li}^{+}$)

4) J. Yin, M. Wada, S. Tanase, and T. Sakai, J. Electrochem. Soc., 151, A583 (2004).

5) H. Yoshinaga, J. Asai, M. Wada, K. Yamamoto, and T. Sakai, Electrochemistry, 73, 897 (2005) [in Japanese] .

6) J. Yin, M. Wada, K. Yamamoto, Y. Kitano, S. Tanase, and T. Sakai, J. Electrochem. Soc., 153, A472 (2006) .

7) H. Sakaguchi, A. Seta, and T. Esaka, Proceedings of the 46th Battery Symposium in Japan, p.486 (2005) [in Japanese].

8) N. Shibamura, T. Esaka, and H. Sakaguchi, Proceedings of the 47th Battery Symposium in Japan, p.434 (2006) [in Japanese]. 